\section{Human genome sequencing plan wins unanimous approval in US}

Gaithersburg, Maryland

THE project to map and sequence the human genome is now a big step nearer reality. At a meeting here last week, the Health and Environmental Research Advisory Committee (HERAC) of the Department of Energy (DoE) collectively took a deep breath and voted unanimously to approve in principle a draft report urging that $\$ 1,000$ million should be spent over the next seven years on the project.A final version of the report incorporating certain drafting changes is expected within four weeks.

Early goals for the DoE's efforts should be to make a physical map of the human genome. The first five years of the project would also see the development of new cloning and sequencing technology, sequencing of selected chromosomal regions and new means for handling data. The work would be done by DoE's national laboratories, as well as by universities and industry. But the HERAC subcommittee also says that there should be a place in the project for research proposals from single investigators as well as multidisciplinary consortia. The committee recommends establishing two scientific panels, one to set goals and the other to review achievements.

Alvin Trivelpiece, director of the Office of Energy Research, asked HERAC to provide DoE with scientific advice on how and whether to proceed with "a potential major new initiative in human genome sequencing". Ignacio Tinoco of the University of California at Berkeley headed a subcommittee consisting of many of the leading lights in molecular genetics who wrote the report

The energy department has already begun work on some of these objectives. The department has requested $\$ 11.5$ million in its 1988 budget for genome project activities. The HERAC report says that this figure should be doubled and that funds should increase linearly between now and 1993 to a plateau of $\$ 200$ million a year.

Charles DeLisi, head of the DoE's office of health and environmental research and a moving force behind DoE's efforts, says the decision to request additional funds rests with Trivelpiece's office. But Trivelpiece will be leaving DoE this month, and will be replaced at least temporarily by his deputy James Decker. Although characterized as an enthusiastic advocate of the project, Decker may not be willing or able to push a major new initiative for DoE. DeLisi may also leave DoE this year to take an academic position, but he believes the project has sufficient momentum to continue without him.

Congress is also a potential barrier to a fully fledged mapping and sequencing project. Few in Congress will be enthusiastic about a new initiative that will cost more than $\$ 1,000$ million, although this is less upsetting than the estimate of $\$ 3,000$ million initially quoted for the project (see Nature 321, 371; 1986)

The HERAC report is at pains to explain why DoE should organize and administer the human genome initiative. Apart from the agency's long-term interest in the health effects of radiation, the draft report asserts that DoE has "unique capabilities to manage this initiative". While calling for cooperation among organizations involved, both domestic and international, the report nonetheless calls on DoE to implement its plans without delay and to take a lead in the project

DoE's interest in becoming the lead agency does not necessarily sit well with other agencies that will be involved. James Wyngaarden, director of the National Institutes of Health (NIH), says it is presumptuous of an agency to claim a leadership role in a project on which it is at present spending less than $\$ 10$ million a year. Wyngaarden says NIH spend nearly $\$ 300$ million a year for research that deals at least in some part with sequencing and mapping human genes. the White House Domestic Policy Council looking at federal activities in the field.

Even as federal agencies debate the relative merits of the genome project, a private corporation has set out to beat everyone to the punch. Walter Gilbert of Harvard University has founded the Genome Corporation which, he says, will work out a cosmid map of the human genome for sale to anyone who may want it. He also intends to sequence segments of the genome, marketing a database containing that information.

Gilbert expects that customers will include the academic research community as well as the pharmaceutical industry. For the moment Genome Corporation exists only on paper, but Gilbert expects the company to be running by summer.

Gilbert will not speculate publicly on how long his mapping and sequencing effort will take, but admits that his timetable "is generally more aggressive than other people's". Gilbert also reckons the entire sequencing effort will cost far less than the DoE estimates - more like $\$ 300$ million - and could be accomplished within a decade by a modestly sized private company. Opinion is divided on whether Gilbert will be able to make a financial success out of the Genome Corporation, but his reputation forces most to take his efforts seriously. Joseph Palca
Wyngaarden is chairing a task force for
Soviets drill in Cyprus London

Two research vessels, belonging to the Soviet Academy of Sciences, will shortly begin geological prospecting off southern Cyprus. The survey will form part of an international programme of research drilling into the Earth's crust and Cypriot scientists have been invited to participate.

Offshore resources are a delicate matter in the eastern Mediterranean and Aegean (see Nature 326, 233; 1987), because of conflicting claims to territorial waters and the possibility of fossil fuels in the area. In the case of the forthcoming Soviet expedition, the official announcements are somewhat conflicting. On 12 March, the Soviet Ambassador in Nicosia, Yurii Fokin, said that the main purpose of the operation would be to map the "complicated and unique" geological structure of the deep-water canyon of the eastern Mediterranean at a depth of $10-15 \mathrm{~km}$, and said that at this depth there is evidence that could indicate the presence of oil or natural gas. But the following day an unnamed government spokesman stressed that these explorations are not aimed at oil prospecting. V.R.

\section{Beer gut prize is awarded}

London

Tomas Hokfelt and Viktor Mutt, both professors at the Karolinska Institute of Stockholm, share the 1987 biennial ArtoisBaillet Latour Health Prize for their work on neuropeptides. In fact, 64-year-old Mutt has worked primarily on gut peptides, many of which have later been shown to be neuropeptides, whereas 47 -year-old Hokfelt has concentrated on central nervous system peptides. Given every other year for research with immediate applications, the $£ 83,000$ prize is awarded by a Belgian foundation to which Count Alfred de Baillet Latour donated his shares in Artois Breweries six years before his death in 1980. P.N.

\section{Polish journals cutback}

\section{London}

Poland's economic problems continue to make it impossible for Polish scientists to keep up with foreign developments "on a day to day basis", the Polish Technical Writing Council has noted. At a meeting in Warsaw in March, the council said that "drastic limitations" on hard currency for journal subscriptions and foreign books will prevail. Moreover, shortages of paper and inadequate and outdated printing technology mean that even Polish learned journals have had their print-runs and size reduced, and frequently suffer considerable delays in production. Much subject matter is therefore outdated before it appears, and the "substantive and editorial standards" of these journals have declined considerably. 